\title{
Online Contract Worker Recruitment System at PT Prospera Utama Officers
}

\author{
Euis Sitinur Aisyah ${ }^{1}$, Dewi Lisnawati ${ }^{2}$, Octavia Noer Jasuma ${ }^{3}$ \\ 1,2,3 University of Raharja, Jl. Jenderal Sudirman No.40 Modern Cikokol Tangerang \\ e-mail: euis@raharia.info, dewi.lisnawati@raharia.info, octavia.jasuma@raharia.info
}

\section{To cite this document:}

Nuraisyah, E., Lisnawati, D., \& Jasuma, O. (2020). Online Contract Worker Recruitment System at PT Prospera Utama Officers. Aptisi Transactions on Management (ATM), 4(2), 114-126.

DOI:

https://doi.org/10.33050/atm.v4i2.1286

\begin{abstract}
Human Resources (HR) One of the main keys in the process of finding a professional and qualified workforce. In order to attract attention to applicants, namely information sent through the website so that information can be accessed and choose people who meet job requirements. All companies in any industry can benefit from contingency or maintain professional recruitment or outsourcing processes for recruitment agencies. The employee recruitment system receives importance in the process of inputting and processing, because it makes it easier for the admin to input the ongoing recruitment and selection process. However, the recruitment system is currently related to anything related to data because the paper is scattered. From these considerations, it is necessary to develop the recruitment so that it can be accessed on the system so that it becomes more systematic, organized. In the development of this recruitment system using the method of swot analysis and elicitation. And use one of the PHP programming language, the data base-server uses MySQL. The results achieved from the analysis of the system used by the author is to use UML (Unified Modeling Language). The results of this study are recruitment systems that can be stored more neatly and help the admin when inputting recruitment during the selection process.
\end{abstract}

Keywords: Recruitment, Information and Applicants

\section{Introduction}

The development of technology is currently growing rapidly, almost all activities follow the progress, especially in the field of information technology. Thus, it is very big to help the community in obtaining information precisely, accurately and quickly. The internet is a medium of information technology that has enormous benefits for society and becomes a necessity that cannot be left behind at this time. With the development of information technology that is growing rapidly at this time, it is very much in need of quality human resources (HR) and can follow the current of globalization which is now thick with technology science. In looking for job information, usually applicants still use conventional methods, namely by visiting the company to see bulletin boards or notice boards. 
All company activities are inseparable from the computerized system, ranging from correspondence, input job applications, making reports to the personnel department to the making of other reports. The use of computers can make it easier for us to do work ranging from inputting data, storage, to archiving data. So when we need that data back we can easily find the data.

With a computerized information system, almost all activities that follow progress, especially in the field of information technology, so that it is very large to help the public in obtaining information on data management precisely, accurately and quickly.

Recruitment of employees at PT Prospera Perwira Utama is a process to obtain quality human resources (HR), which are used to support the performance of a company. To get quality human resources, the recruitment process for new applicants is very strict. Prospective workers who will apply for a job must be in accordance with the desired criteria and have strong competence in the fields that apply in the company. At the time of this thesis research, recruitment at PT Prospera Perwira Utama was computerized using MS Excel. This results in applicant's pile up files and delays in getting information about prospective workforce data, and requires more time to collect applicant data. Therefore, a recruitment system is needed to use internet facilities which are currently the information media. Where the recruitment application can store prospective workforce curriculum vitae data more neatly and well structured, so that later it will be able to provide recommendations to the Human Resources Department of PT Prospera Main Officer, to receive some prospective workforce candidates with the highest cumulative score for selection to the next stage.

Based on the problems described above, the authors take the title "Online Employment Contract Recruitment System at PT Prospera Utama Officers" to facilitate the recruitment process effectively both effectively in time and process flow.

\section{Research Method}

\subsection{Data Collection Methods}

There are 3 (three) data collection methods used, namely:

\section{Observation Method}

The purpose of the authors make the method of observation is to obtain information on existing problems directly so that researchers can pour accurate information through this report.

\section{Interview Method}

The research began with an interview process with stakeholders, namely Mr. Stefanus Wijaya HRD PT. Prospera Main Officer, to obtain data and information in the form of needs needed by PT. Prospera Main Officer in innovating and developing is better than before.

\section{Library Study Methods}

Doing research by reading and studying theories related to research. These theories are sourced from national scientific journals, international scientific journals, as well as other sources that have validity and credibility so that they form the basis of a clear and informative theory.

\subsection{System Analysis Method}

The analytical method used in this study is the SWOT (Strengths, Weakness, Opportunities, Threats) analysis method.

\subsection{Design Method}


The design process used to create a Recruitment System is by using a Unified Modeling Language (UML) tool in the form of Use Case Diagrams, Sequence Diagrams and Activity Diagrams, and Class Diagrams.

\subsection{Testing Methods}

Testing is a process of program execution to look for and find errors (errors) before being used by end users (end-users). One of the testing methods used is the Black Box Testing method.Tables and Figures are presented center, as shown below and cited in the manuscript.

\section{Results and Analysis}

\subsection{Analysis of Current Systems}

In analyzing the current system there is a SWOT Analysis method which consists of 2 (two) factors, namely Strength and Weakness as internal factors, as well as Opportunities and Threats which are external factors that will be faced by PT. Prospera Chief Officer. The following is a SWOT identification matrix table at PT. Prospera Chief Officer:

\begin{tabular}{|c|c|}
\hline Strenghts (S) & Weakness (W) \\
\hline $\begin{array}{l}\text { 1. Make it easy for applicants to get } \\
\text { information } \\
\text { 2. Perform services in handling } \\
\text { recruitment properly. }\end{array}$ & $\begin{array}{l}\text { 1. Applicants must come to the } \\
\text { company to put a job file or } \\
\text { application letter. } \\
\text { 2. Data storage is less effective so } \\
\text { data is often lost. }\end{array}$ \\
\hline Opportunuities (O) & Threats $(T)$ \\
\hline $\begin{array}{l}\text { 1. More efficient use of time. } \\
\text { 2. Utilization of technology that has } \\
\text { developed. } \\
\text { 3. Utilization of workforce reduction. }\end{array}$ & $\begin{array}{l}\text { 1. The existence of companies } \\
\text { engaged in the same field of } \\
\text { domestic and foreign companies } \\
\text { makes the competition tougher. } \\
\text { 2. Fraud job vacancies that cause } \\
\text { harm to applicants. }\end{array}$ \\
\hline
\end{tabular}

Table 1. SWOT identification

Based on the identification of the SWOT analysis conducted, an analysis is then performed to find a strategy using the SWOT matrix. The SWOT matrix can clearly describe the opportunities that exist using (SO strategy) and use its strengths to overcome threats with (ST strategy) and also analyze strategies to reduce the 
weaknesses that are owned to seize the opportunities that exist using (WO strategy) and overcome threats by (WT strategy). The following is the SWOT matrix can be seen in the table below:

\begin{tabular}{|c|c|c|}
\hline & STRENGHTS & WEAKNESS \\
\hline \multirow[b]{2}{*}{ 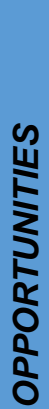 } & STRATEGI S-O & STRATEGI W-O \\
\hline & $\begin{array}{l}\text { Designing a recruitment } \\
\text { system as a system of job } \\
\text { vacancy information where } \\
\text { applicants can fill out } \\
\text { recruitment to be more well } \\
\text { controlled because only by } \\
\text { visiting through the website. }\end{array}$ & $\begin{array}{l}\text { Designing a recruitment system } \\
\text { as a system of job vacancy } \\
\text { information so that it can be } \\
\text { accessed anywhere without } \\
\text { having to come to the company. }\end{array}$ \\
\hline \multirow[b]{2}{*}{ 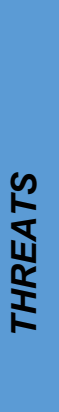 } & STRATEGI S-T & STRATEGI W-T \\
\hline & $\begin{array}{l}\text { Socializing } \\
\text { applicants about the } \\
\text { existence of a system for } \\
\text { inputing and processing } \\
\text { recruitment } \\
\text { information ab } \\
\text { employment. about }\end{array}$ & $\begin{array}{l}\text { Implement a recruitment system } \\
\text { as a system of job vacancy } \\
\text { information so that it can be } \\
\text { done anywhere and the input } \\
\text { and processing of recruitment } \\
\text { will be saved. }\end{array}$ \\
\hline
\end{tabular}

Table 2. SWOT Analysis of Current Systems

\subsection{Proposed Program Design}

\section{Initial appearance of the Recruitment website}

The Recruitment System is now based on the website and can be accessed by both applicants and admins anytime and anywhere, thus making the recruitment process more efficient and effective.

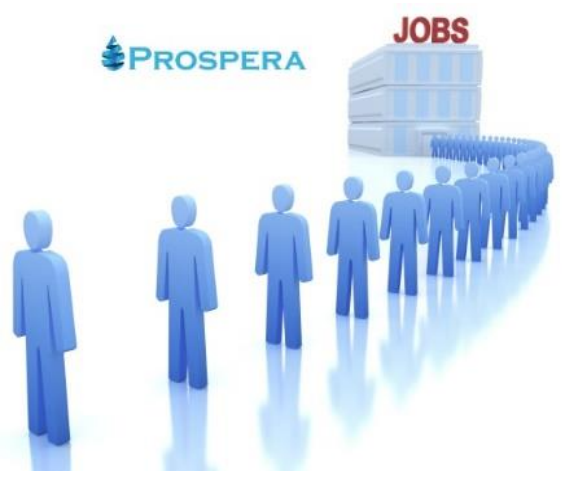

Picture 1. Initial appearance of the Recruitment website 


\section{Job Menu Menu Display}

There are 2 choices of page views namely Information for applicants and Input for admins. The applicant's page display then appears informing what is needed for the applicant.

fProspera

Beranda Profil Perusahaan Lowongan Kerja

\section{LOWONGAN KERJA}

T. Prospera Perwira Utama adalah sebuah perusahaan pengadaan alat-alat IT

(information technology) yang berlokasi di Crown Green Lake City. Perusahaan ini

memberikan penyediaan solusi dan layanan perangkat keras serta perangkat lunak

tingkat operator yang inovatif. Yang membantu bisnis sepenuhnya mewujudkan janj teknologi dan membantu memaksimalkan nilai teknologi yang Anda butuhkan.

SPROSPERA

\section{Opened}

ADMIN KANTOR

PT. Prospera Perwira Utama adalah

sebuah perusahaan pengadaan alat-alat

IT (information technology) yang

bergerak di bidang Network

Infrastructure.

Details

Picture 2. Job Menu Menu Display

3. Job Menu Detail Page Display

4. J

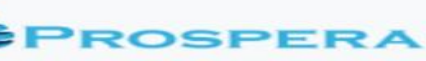

Picture 3. Job Menu Detail Page Display 


\section{Display List Menu Page}

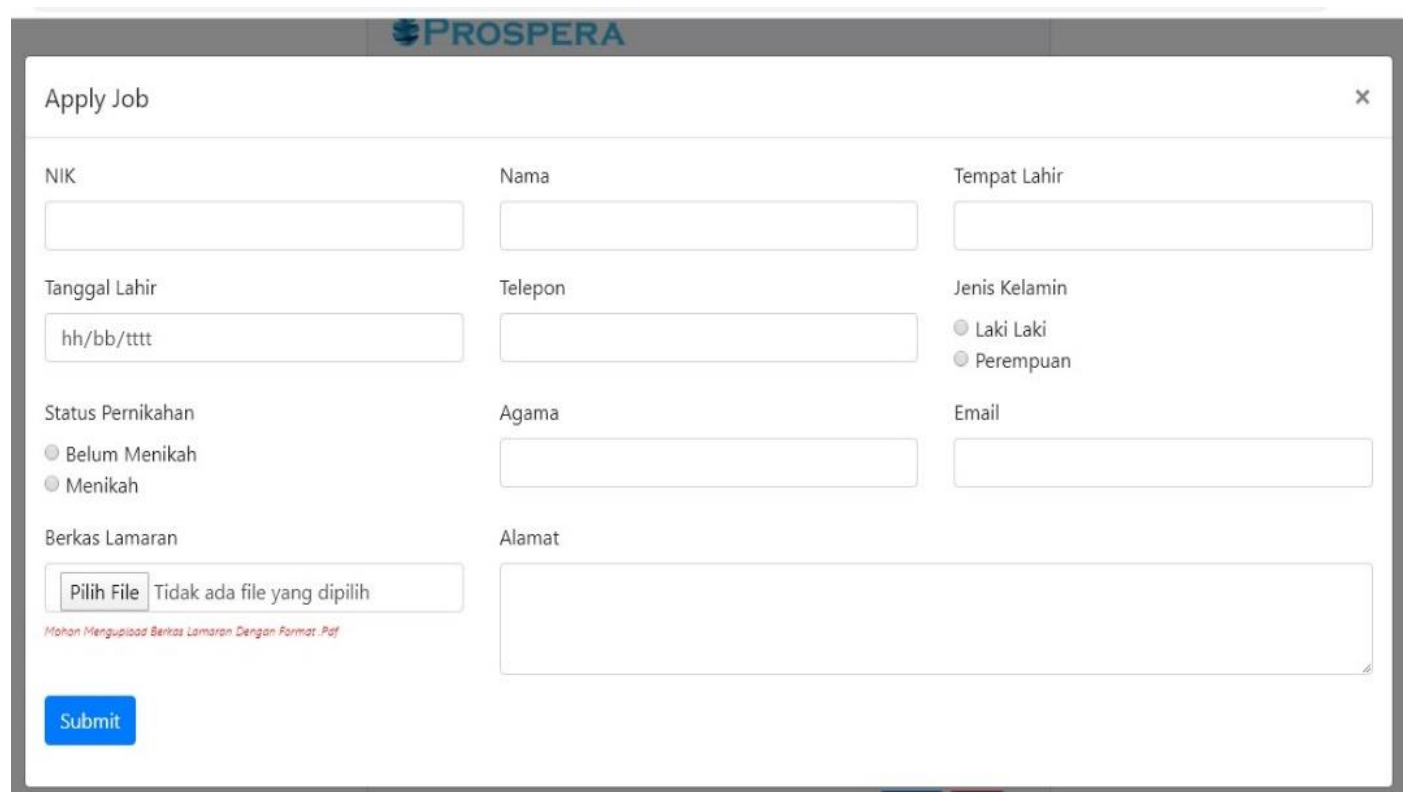

Picture 4. Display List Menu Page

\section{Display the Test Schedule Menu Page}

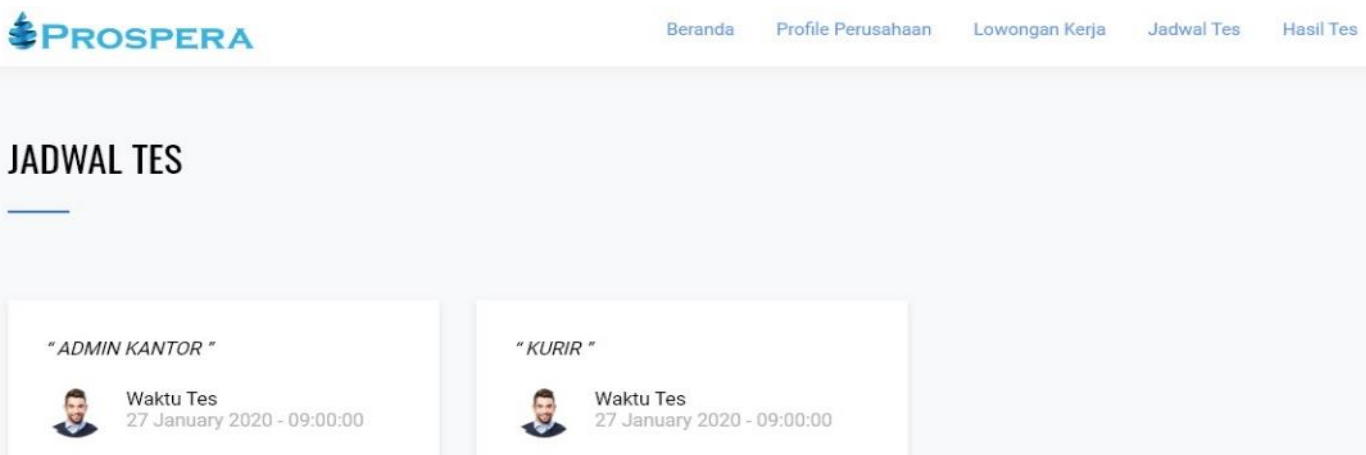

Picture 5. Display the Test Schedule Menu Page 


\section{Company Profile Menu Page Display}

is a brief description / history of the company.

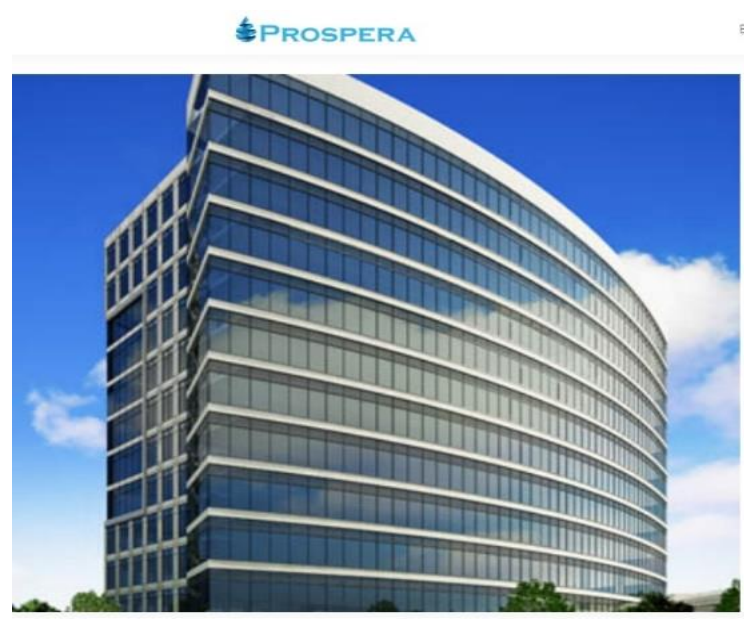

Profil Prospera

T. Prospera Perwira Utama adalah perugahaan yang memberikan solusi di bidang Network Infrastructure melingkupi (Konvensional Server, Hyperconverge Server Storage kami meberikan solusi di bidang piranti lunak (Sistem Apikasi).

Kami telah berpengalaman lebih dari 5 tahun dalam mendistribusikan produk - produk hami yang berkualitas dan terjamin.

Kami juga telah berpengalaman dalam bekerja sama dengan HP, DELL, LENOVO, ASUS Nutanix, CITRIX, PALO ALTO, JUPITER, BLUE CODE, Mellanox, ARRISTA, al.

Kami berkomitmen untuk membantu bisnis sepenuhnya mewujudikan jani teknologi dan membantu memaksimalkan nilai teknologi yang dibutuhiken.

Picture 6. Company Profile Menu Page Display

7. Login Page Display

Enter login: fill in user and password for Admin / HRD

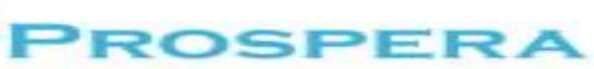

Picture 7. Login Page Display 
8. Display Admin / HR Start Page after logging in

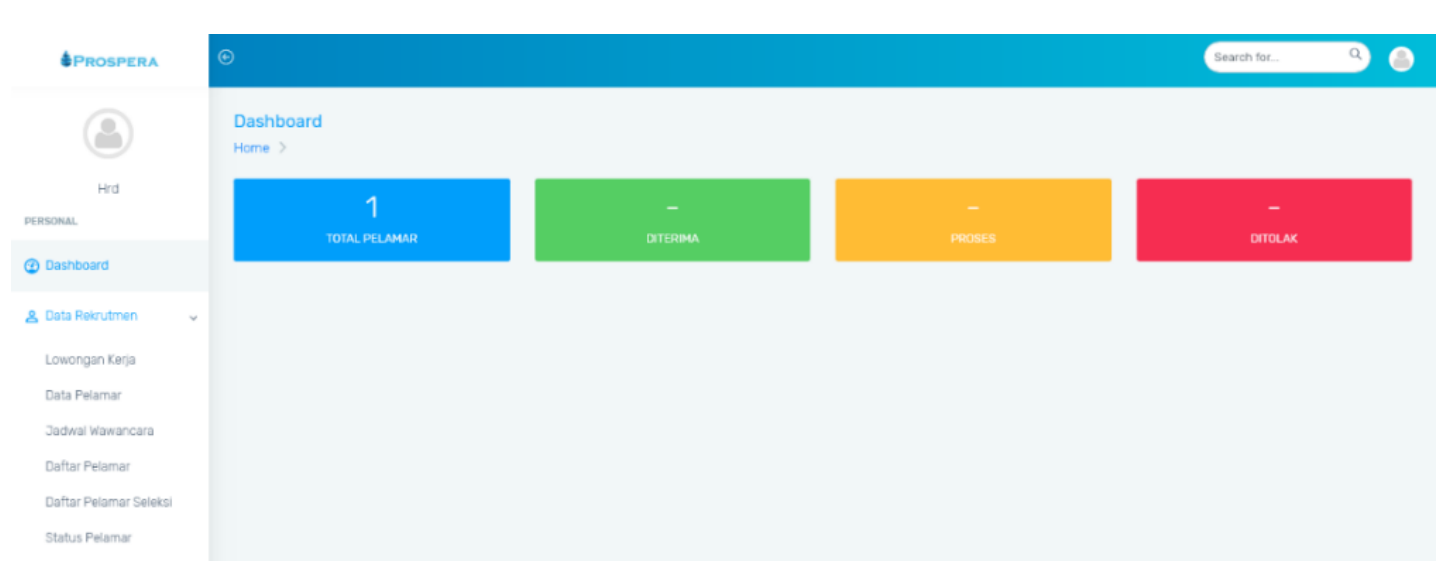

Picture 8. Display Admin / HR Start Page after logging in

9. Job Input Input Page Display

Admin input is a vacancy.

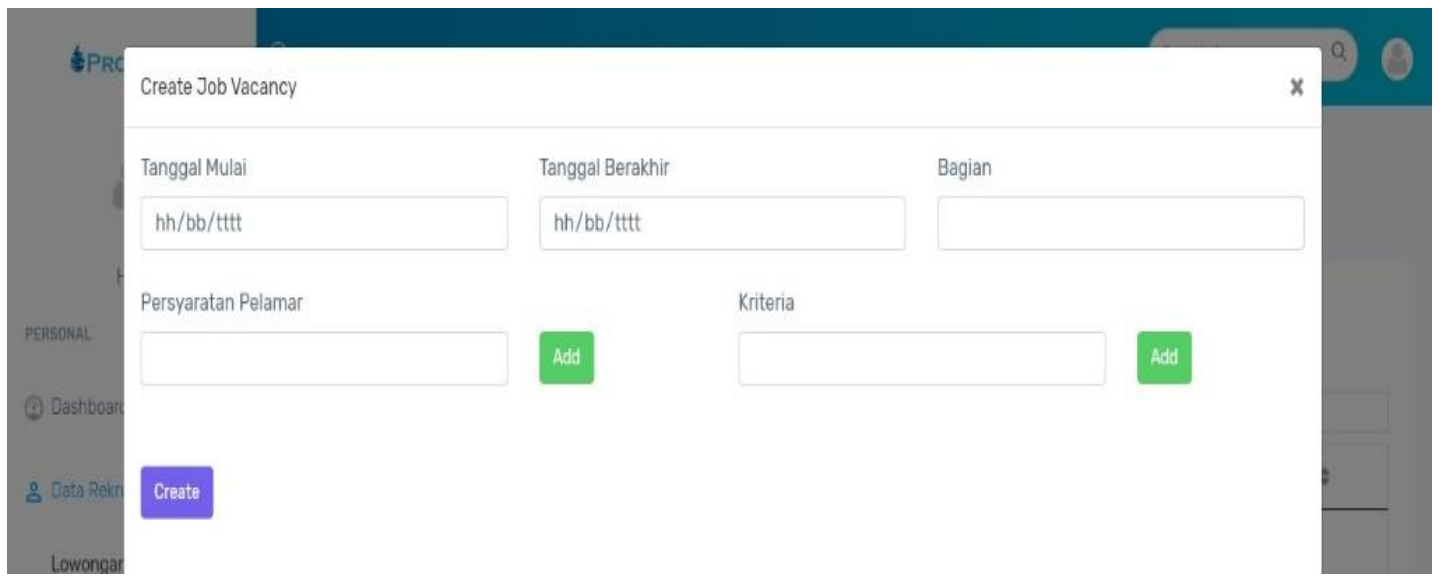

Picture 9. Job Input Input Page Display 
10. Display Applicant Data Page

is containing data on applicants who apply for jobs and complete pdf file files.

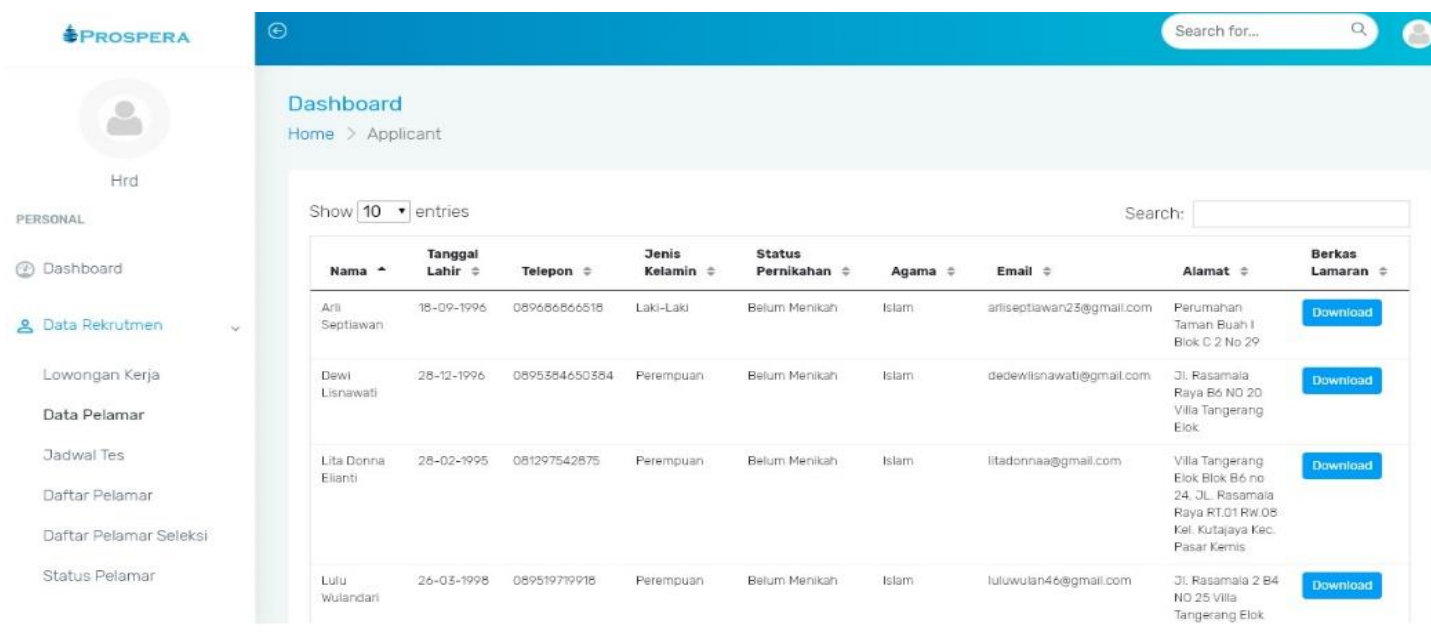

Picture 10. Display Applicant Data Page

11. Input Page Test Schedule Input

Admin / HR is inputting the value of prospective employees who have done the test.

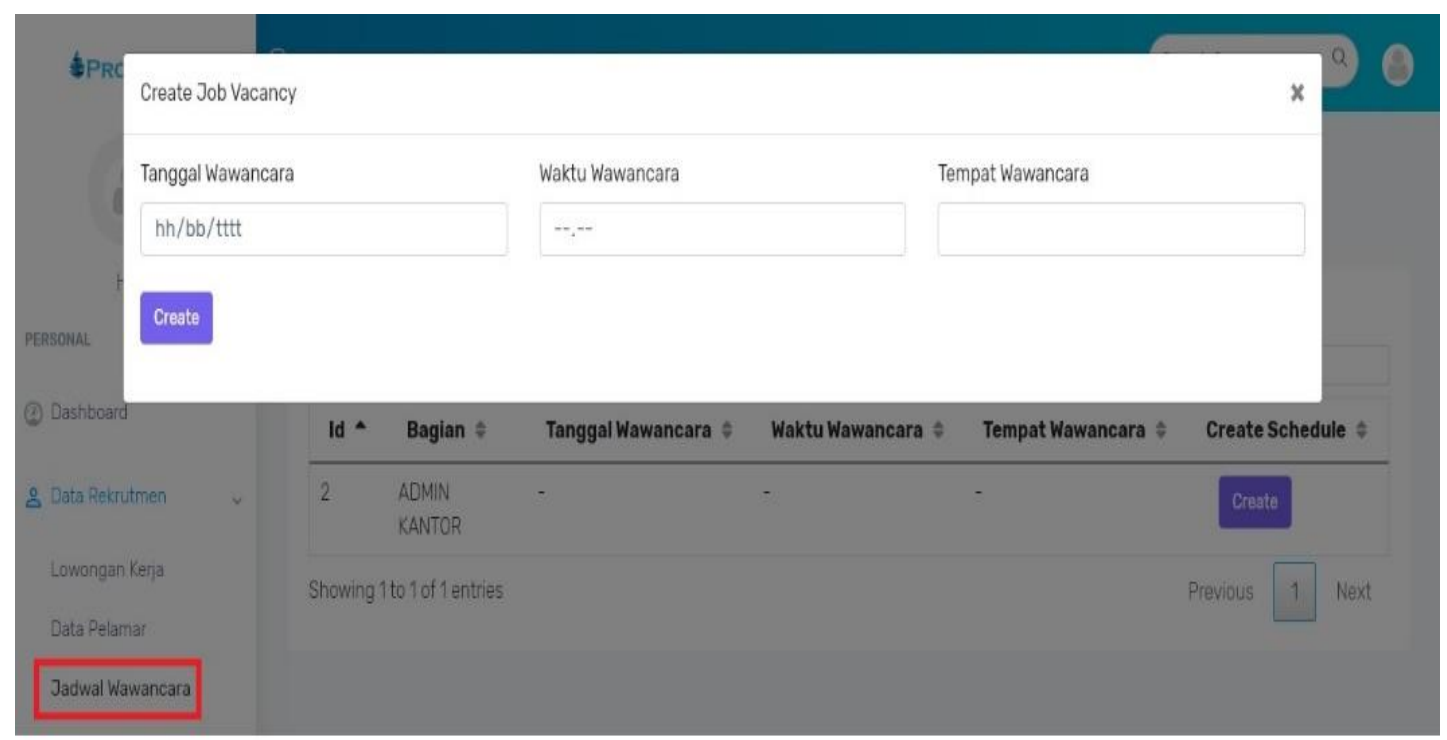

Picture 11. Input Page Test Schedule Input 
12. Display Input Test Page Value

is an input test score for prospective employees who get a test call.

\section{\$PROSPERA}

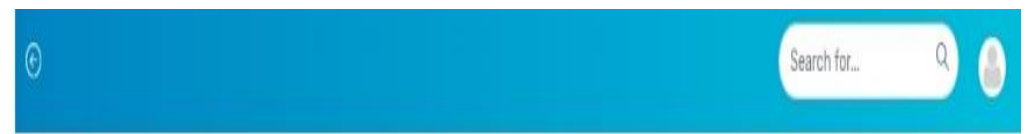

Dashboard

Home > Show

Hird

Personal

Nilai interview

\section{Nilai Tertulis}

(2) Dashiboard

\& Oata Rekrutmen

Picture 12. Display Input Test Page Value

\section{Display the Applicant Status Page}

is a list of applicants who are accepted, rejected, and still in the process of updating.

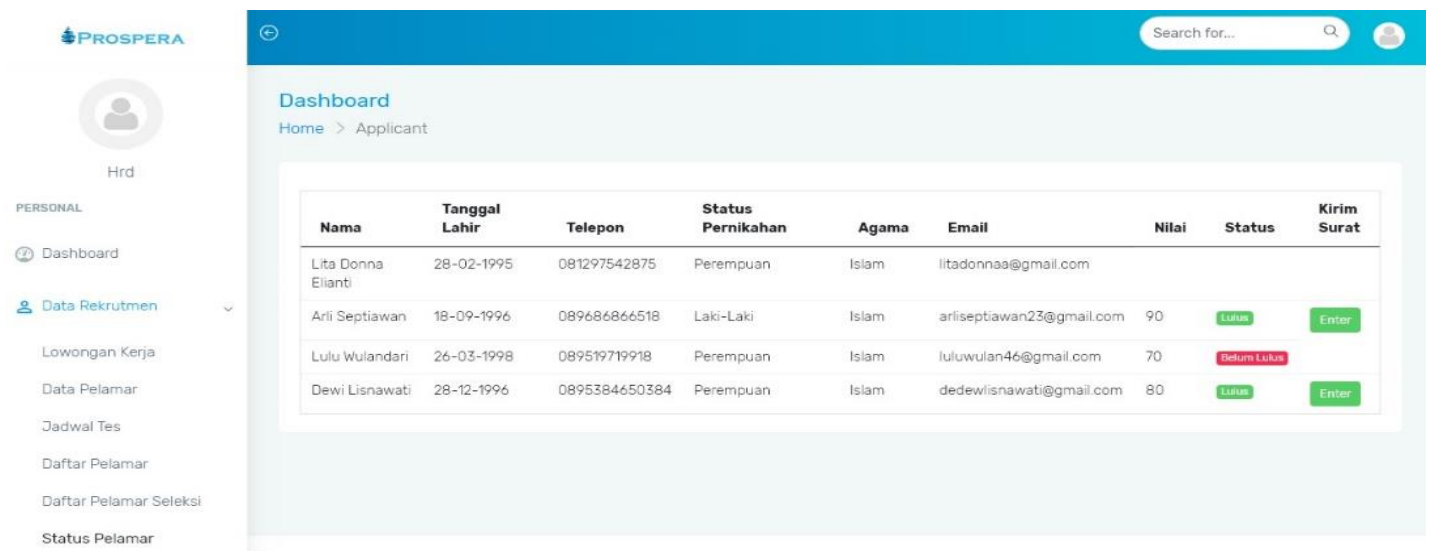

Picture 13. Display the Applicant Status Page 


\section{Difficult Page Display of results of applicants who pass the test}

The display contains reports for applicants who passed the test

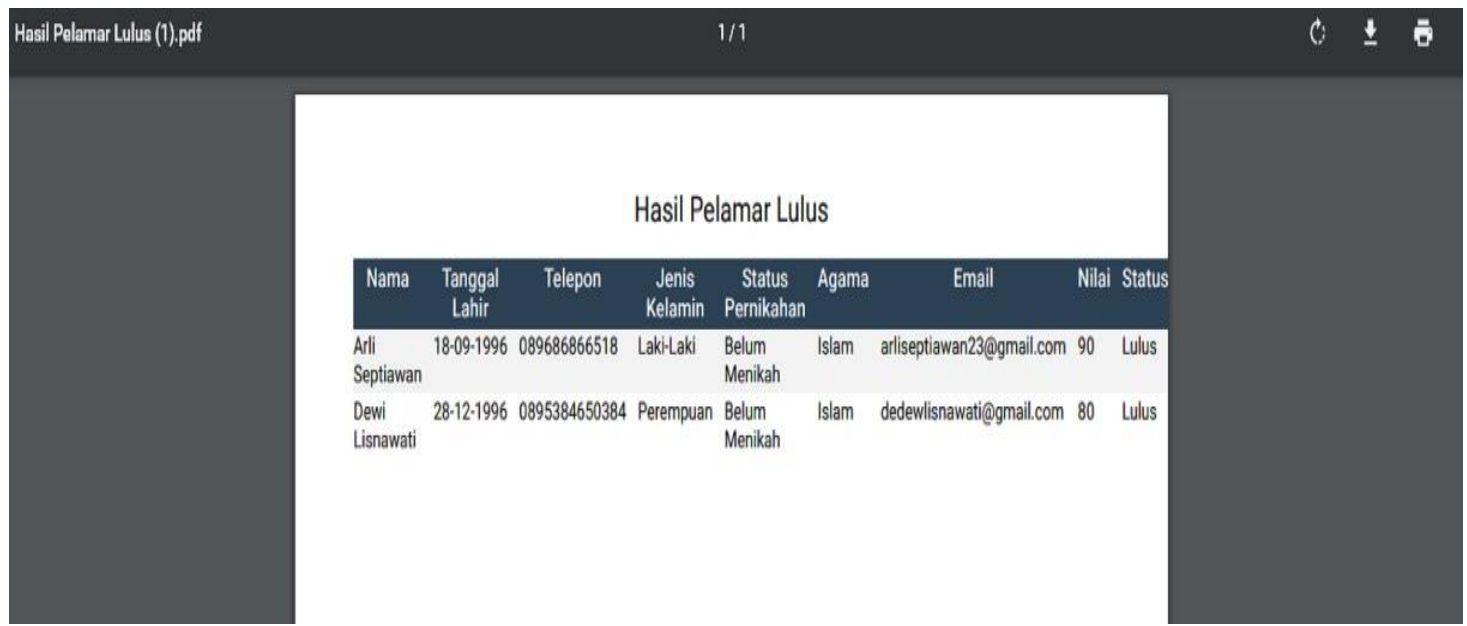

Picture 14. Difficult Page Display of results of applicants who pass the test.

\section{Conclusion}

Based on the analysis of the problems outlined in the previous chapter, conclusions can be drawn from the formulation of the problem regarding the labor distribution system, as follows:

1. Requires a recruitment application system that can help prospective employees to more easily obtain vacancy information and apply for jobs online.

2. Can cause errors when registering prospective employees, and pile up files so that fear of losing files.

3. Information systems designed with web-based use MySQL database, PHP Laravel framework, system design with UML, testing using Black Box Teting, the analysis method used is using the SWOT Method. 


\section{References}

[1] Herlina Wati, Ratna,. Arief Saptono dan Jefri Rivaldi Nainggolan. 2017. Perancangan Sistem Informasi Seleksi dan Perekrutan Calon Karyawan. Jurnal Maklumatika Vol.3 No.2 Januari 2017 ISSN: 2407-5043.

[2] Iskarim, M. (2017). Rekrutmen Pegawai: Starting-Point menuju Kinerja Organisasi yang Berkualitas dalam Perspektif Manajemen Sumber Daya Manusia dan Islam. Manageria: Jurnal Manajemen Pendidikan Islam, 2(2), 307-327.

[3] Kurniawan Atmoko, Freddy. 2017. Pemakaian Rekrutmen Online Di Indonesia Pada Perusahaan-Perusahaan Terdaftar Di Bursa Efek Indonesia. Jurnal AGORA Vol.5 No.3.

[4] Niharika, M.Reddy dan T. Mamatha.2017. "Development of E-Recruitment portal for IT Industry with Effective Fraud Detection". International Journal of Innovations \& Advancement in Computer Science IJIACS .ISSN 2347-8616 Volume 6, Issue 10.October 2017.

[5] Oaya, Z. C. T., Ogbu, J., \& Remilekun, G. (2017). Impact of Recruitment and Selection Strategy on Employees' Performance: A Study of Three Selected Manufacturing Companies in Nigeria. International Journal of Innovation and Economic Development, 3(3), 32-42.

[6] Rahayu, S., Azizah, N., \& Ferlyawan, R. (2018). IMPLEMENTASI SISTEM INFORMASI PADA E-RECRUITMENT CALON KARYAWAN. SENSI Journal, 4(2), 141-152.

[7] Vinayaka M.C, Mr., and Dr. S. Ramaswamy. 2017. Recruitment Process and Practices Undertaken in IT Sector: A Comparative Analysis of Selected Indian and MNC Companies. Imperial Journal of Interdisciplinary Researc(IJIR) Vol.3 Issue 2 ISSN: 2454-1362. 